\title{
WHICH IS MORE TRUSTWORTHY: GOOGLE OR DOCTOR? A RECEPTION ANALYSIS OF MEDIA AS HEALTH EDUCATOR
}

\author{
Desi Yoanita $^{{ }^{*} \text {, Fanny Lesmana }}{ }^{1}$, and Kartika B. Primasanti ${ }^{1}$ \\ ${ }^{1}$ Department of Communication Science, Faculty of Communication Science, Petra Christian University \\ Jl. Siwalankerto 121-131, Surabaya 60236, INDONESIA \\ * Korespondensi penulis, e-mail: dy-nita@petra.ac.id
}

\begin{abstract}
As media develops as a primary source of health information, two questions remains: How people receive online media as a source of health education? and what group of people will tend to use online media intensively than others? Although government has provided various ways to fulfill people's health needs has been considered a development on health policy in Indonesia, examining contemporary situation and current online media development reveals a need for exploring how people receive online media as health educator. This research study depicted how people from a certain background receive online media as health educator. Using a reception analysis, the research study has conducted through several processes of interview and observation with some selected informants. The research study revealed that different people from different background would receive online media as their health educator from different levels. From this research study, the researchers concluded that the three informants receive online media as their primary health educator. However, because of their educational, motivational, social and technological access, they performed different approach of receiving online media as their health educator.
\end{abstract}

Keywords: Reception, health, educator, doctor, online media, google.

\begin{abstract}
ABSTRAK
Media telah berkembang menjadi pusat informasi di bidang kesehatan, meskipun demikian tetap timbul dua pertanyaan terkait hal tersebut: Bagaimana masyarakat menerima media online sebagai sumber pendidikan kesehatan? dan kelompok masyarakat seperti apakah yang cenderung menggunakan media online lebih intensif dari yang lain? Meskipun pemerintah telah menyediakan cara yang bervariasi untuk memenuhi kebutuhan kesehatan masyarakat, melihat situasi media online saat ini dibutuhkan pengujian untuk mengetahui bagaimana masyarakat menerima media online sebagai sumber pendidikan kesehatan. Penelitian ini menggambarkan bagaimana masyarakat dari kalangan tertentu menerima media online sebagai sumber pendidikan kesehatan. Menggunakan reception analysis, penelitian ini dilakukan melalui proses wawancara dan observasi kepada beberapa informan terpilih. Hasil penelitian ini menunjukkan bahwa latar belakang masyarakat menentukan bagaimana mereka menerima media online sebagai sumber pendidikan kesehatan. Ketiga informan dalam penelitian ini menerima media online sebagai sumber utama pendidikan kesehatan, namun terdapat cara pendekatan yang berbeda dari masing-masing informan, terkait dengan latar belakang pendidikan, motivasi, lingkungan sosial, dan akses teknologi.
\end{abstract}

Kata kunci: Penerimaan, kesehatan, pendidik, dokter, media online, Google.

\section{INTRODUCTION}

Online media provides a great opportunity for people to access health information easier than before. Two of Indonesian leading news media, Liputan6.com (2014) and tempo.com (2013) noted that a poll in British showed that women tend to see google or other search engine rather than see a primary physician when their children are sick. Some of these respondents said that they felt that the doctors did not really listen to their problem. According to that reports, the respondents found that doctors have different information from what they got from online media. Moreover, recently, internet has become a notable resource for people to seek health information worldwide (Fox, 2010; Fox and Jones, 2009; Lewis, 2006; Mager, 2009; Wyatt et al., 2005 in Thomson, 2012). Thomson (2012) stated, "transformation in digital technology have allowed web designers to bring together visual, textual, and audio forms to communicate messages quite differently to the modern day internet audience." Thus, regarding people's need to seek health information, internet is considered user friendly. As the consequence, instead of spending their money in a consultation session with a physician, people feel more comfortable to search health information from online media. 
In Indonesia, where not all citizens have access to health education, this phenomenon becomes intriguing. It is noted that Indonesia's health development is far behind Singapore, Thailand, Malaysia, Vietnam, and Philippine (kompas.com, 2013). The lack of health experts and health facilities, which are affordable for all people, are the causes of this issue. Several problems considered as factor for health issue in a developing country, such as Indonesia, are extreme poverty and insufficient health education (Kaye \& Novell, 1994). As a consequence, most of Indonesian residence will not be able to neither afford sufficient health treatment nor being motivated to seek health experts. As the solution, for the lowincome group, "The government of Indonesia demonstrated its commitment to primary health care by establishing local health posts, namely posyandu, first in rural areas and more recently in cities" (Kaye \& Novell, 1994). However, the middle-income group is the one who experience difficulty to access health treatment because they would not go to the facilities provided for the low-income group yet they would not be able to afford higher quality treatment. Even though the government has provided insurance through Badan Penyelenggara Jaminan Sosial (BPJS) or free health treatment, the coverage does not represent the needs of all Indonesian people. Therefore, instead of going to see doctor, people would tend to look for alternatives, such as seeing traditional health treatment or looking for information in media.

As media becomes an accessible source to educate people regarding health issues, the questions are: How people receive online media as a source of health education? and what group of people will tend to use online media intensively than others? Although government has provided various ways to fulfill people's health needs has been considered a development on health policy in Indonesia, examining contemporary situation and current online media development reveals a need for exploring how people receive online media as health educator. The researchers used a reception analysis method to depict how several people from various backgrounds in Indonesia perceive online media as their health educator.

\subsection{Research Question}

1. How do people receive online media as a health educator?

2. What group of Indonesian people would strongly receive online media as their health educator?

\subsection{Research Objectives}

This research study focused on describing how people from several backgrounds, such as socio-economic, culture, and region, in Indonesia perceive online media as one of health resources. The need to depict this phenomenon was based on the development of internet to replace "face to face" health consultation with online media surfing. This research would be a preliminary research to determine how far people in a developing country such as Indonesia perceive online media as an educator regarding their health problem and to portray what kind of Indonesian people group use online media more intensively as their health educator.

\section{LITERATURE REVIEW}

The literature review section of this study examined several literatures as guidance to understand how people perceive online media as their health educators. To date, this section provides two main discussions on the role of medium in health the communication and the development of online media in a developing country. As for the main concept of this research study, the health communication was defined as a study which "use communication strategies to inform and influence individual and community decisions that enhance health" (2001; U.S. Department of Health and Human Services, 2005).

\subsection{Role of Online Media in Health Communica- tion}

Humpreys, Rodger, and Flabouris (2013) found that social, digital, and online media is a possible resource in health promotion. These researchers incorporated a framework of medium theory to determine social and power as factors, which related to the use of online media as health resources. Through this research study, the researchers examined the attitudes of health professionals in providing health information and discussion in online literatures. This research study found that online literatures were used to provide not only static information but also dynamic news such as the relationship between patients, doctors, and hospital staff. However, this research conducted only in a metropolitan hospital setting so. Thus, the findings were not sufficient to be discussed in lower economic context.

Another current research study, which discussed the role of online media in health education, was Effect of 
Online Health Sources on Credibility and Behavioral Intentions conducted by $\mathrm{Hu}$ and Sundar (2010). This research study portrayed how typology of online sources influenced the perception of credibility and behavioral intention toward health communication. The researchers found that people preferred to use website than personal blog or homepage. According to the result, the selection of source people cite was based on information completeness. In addition, $\mathrm{Hu}$ and Sundar (2010) reported, "The analysis also yielded a three-way interaction between message, original source, and selecting source on perceived credibility, suggesting the operation of an appropriateness heuristic when evaluating source combinations for less relevant health topics" (par. 1, abstract).

The last research study cited in this discussion was regarding the understanding of using online media as health promotion (Korda \& Itani, 2013). This study suggested that health professionals need to arrange a careful application and plan an evaluation to obtain the effectiveness of various online media. The conclusion of this research study stated that professionals need to leverage online media to promote health information. First, it was because online media considered inexpensive source. Korda and Itani (2013) stated, "The benefits of social media's inexpensive, broad reach can quickly become information overload. At what point will applications considered novel today lose the attention of the audiences they seek to target? Can social media interventions maintain intention as well as attention? Researchers report that consumers readily "game" online programs, especially when incentives such as gift cards or cash are offered. Although these activities can be tracked with analytics that identify respondents' IP addresses, getting around the rules is not difficult" (p. 21). At the end of this study, the researchers questioned the difficulty to determine the people's intention in using online media, whether they are just "stopping by" or actually engaging with the content.

\subsection{Online Media in a Developing Country}

The using of online media has been shaping the practice of health communication (Shciavo, 2008). Thus, Shciavo listed the ways to use online media has been developed. Nowadays, there are various forms of online sources for health information and communication, such as website, internet-based games, online press room, diseases symptom simulations, opinion polls, seminars, and personal blogs or podcasts. According to Schiavo (2008), the use of internet for health communication or e-health has emerged since 1999. It was defined as "a field in the intersection of medical informatics, public health and business, referring to health services and information delivered or enhanced through the Internet and related technologies" (Schiavo, 2008, abstract). In a developing country, online media develops in a particular way regarding the characteristics of the society. This section pictures of the dynamics of how people use online media in a developing country.

In a study comparing how developing and developed countries participate in online activity, Chang, Y., Wong, F., \& Park, M. (2014) conducted a survey in Korea and Cambodia to found how people in these two countries perceive online media differently. This researcher found that the intention to use ICT and the isolate key factors of the users were different between two countries. Two factors influence the use of online media in these two countries were technological and social access. Fan used a model to distinguish people who have access to ICT and those who have not. This phenomenon was called digital divide. Van Dijk and Hacker (2003) and Chang, et al (2012) cited in Chang, Y., Wong, F., \& Park, M. (2014) proposed four facets as factors of digital divide: technological access, social access, motivational access, and skill access. Chang, Y., Wong, F., \& Park, M. (2014) concluded, "Developed nations benefit from advanced ICT infrastructure and policies that stimulate economic and social growth. Developing nations, on the other hand, are still struggling with basic ICT infrastructure."

\section{METHODOLOGY}

The researchers used a qualitative approach to determine how people receive online media as health educator. This approach was chosen for several reasons. First, according to Slavin (2007), qualitative research aimed to explore social phenomena by "immersing the investigator in the situation for an extended period" (p. 121). Second, people's reception of a media form could not simply be quantified because of its contextual characteristic. Thus, an inductive method was needed in the research process. Third, a qualitative reception analysis could help to uncover a wealth of information concerning how an individual from a certain group or background receive a form of media a particular context.

The reception analysis was conducted to describe how various types of audience members make sense of specific text. Jensen in Jensen and Jankowski (1991, p. 135) stated that reception analysis assumes 
that there can be no "effect" without "meaning". The general finding of reception analysis that audiences reconstruct the meaning of media discourses, to a degree asserting their opposition or difference in discursive terms (p.147). This study aims to determine how audiences interpret the messages conveyed by the online media-related health issues.

According to Baran and Davis (2006), this study focuses on the uniqueness of an individual as media audience, including his or her intellect and ability. Therefore, when selecting informants for this study, the researchers look for a varied characteristic, such as social economy class, education, region, and profession. In accordance with the purpose of this research, the researchers will select at least three informants who considered have access to online media with variety of (a) socio-economic level; (b) education and profession; and (c) cultural background. The data was collected through an interview and observation of the selected participants. In addition to the analysis technique, these researchers develop a matrix as the framework for this reception analysis to structure the study. The matrix was developed based upon the theory of media role model and several elements in reception analysis (see Appendix).

\subsection{Findings and Analysis}

Humpreys, Rodger, and Flabouris (2013) stated that social, digital, and online media is a possible resource in health promotion. Thus, the researchers assumed that certain individual would receive online media as a health educator, which categorized as dominant audience, negotiated audience, or oppositional audience as stated by Hall (1974 as stated in Jensen and Jankowski, 2003). For some people, online media is more accessible and affordable than any other health treatments. In addition, people would think that online media is more trustworthy due to its ability to provide various sources of information. Moreover, other factors such as education, socio-economic, and culture would influence the use of online media in developing country as well as suggested by Chang, Y., Wong, F., \& Park, M. (2014).

Three participants revealed different perspectives of how receive online media as health educators. To determine the level of differences, the researchers asked various questions regarding the participants' relationship with online media, as described in this research study matrix. Those criteria were informants' backgrounds, their relationship with online media, technological access, social access, motivational access, skill access, media forms, benefit, difficulty, how to, using internet as their first or secondary sources, and others question raised in the midst of interview and observation. These criteria were asked toward three informants, which are informant 1 , informant 2, and informant 3 who have different level of relationship with online media.

\subsection{Informant I}

The first informant is 38 years old female who is a housewife. She is a wife of a pastor in Surabaya, Indonesia. She is the first born of five who was born in East Borneo. She has earned her diploma degree in economic banking major. She was considered as Indonesian middle class based on her family monthly cost and earnings. She has strong relationship with online media because she loves to read any information, especially regarding health issue. Thus, having a smartphone, and internet data in it, helps her to fulfill her curiosity of health information. Everyday, before going to bed, she always spent several hours to access any information from the internet even though there is no problem with her health at that time. This is to fulfill her interest in how to prevent illness, such as "if today is a very hot day, what should we do to protect our health?"

From a motivational perspective, beside her young dream to be a nurse, her action of always using internet to find and health information was initiated by a big incident in her life. Once, her first born was sick and was about to die. She had been experiencing high fever for several days and there was no medicine that could help this little boy. She and her husband brought their child to a doctor. However, the doctor could not give any further explanation to help this family. Thus, informant 1 thought that she would probably get information from internet. It was true. She found a blog of a mother whose daughter had the same symptoms of illness. She contacted the owner of the blog and began a consultation with her doctor, which helped her solve her child's health problem. That is to say, informant 1 started trusting online media than her doctor. Several reasons she revealed of not seeing a doctor when she or her family had a health problem were because it was expensive and the doctor was not cooperative. She admitted that she went to a doctor only once a year. Moreover, she mostly did not pick up the medicine recommended by her doctor if she found alternative medicine from the internet, which was cheaper and easier to find. 
Now, online media always becomes her first resources to seek any information regarding health problem. As a housewife, who has a wide social life and technological access, there is no difficulty she finds to always connect with online media. She found that online media is more beneficial than seeing a doctor. She said, "I always do a cross check with various website before deciding a treatment for my family's health problem." Her technological literacy level is sufficient to do a cross and balance of any health information she got from the internet. Using an internet as a health educator has helped her in various ways such as saving money, time, and energy and expand her views of health information. Because of her highly literacy in online health information, her extended family and friends always text her to ask various questions related to their health problem.

\subsection{Informant 2}

The Informant 2 was a 33 years old female from an Indonesian upper class group. She was a professor in well-known private university in Surabaya, Indonesia and a wife of a businessman and financial consultant. Her last education was master degree in communication major. Her hobby are shopping and travelling. She is a very active woman. However, she was the only one who often gets sick in her house.

She has a very strong relationship with online technology as well. She always has the most updated gadget. Now, she has a macbook, an i-pad, an iphone, and several other gadgets she uses to work or having pleasure. She uses her laptop one to two hours a day. She uses her i-pad two hours a day, and she uses her $i$-phone every time. In addition, she has a strong wi-fi connection in her house and in her office. Thus, her technological literacy is in high level.

From a motivational perspective, her action to use online media was initiated by her hesitant to see a doctor because she think she can get exactly the same information from the internet compared to from her doctor. Even though she has many family health care or doctors, she would prefer to see health information from the online media. However, this action is only for her and her husband. As for her children, she would rather to see a doctor if her two children are sick. She does not want to take any risk for her children in this case. She admitted that her family would go to see a doctor in Singapore than in Indonesia for a health treatment. There was a family influence in her decision of seeing a doctor for her children. The traditional view of her family is a reason why she still chooses to see a doctor than seeking information from the internet for their children health problem. Her family believes that doctor is still more trusted than any information from the internet.

\subsection{Informant 3}

The third informant was a 46 years old male. He was a general affair staff in a well-known institution in Surabaya, Indonesia and was considered as Indonesian lower class group. He has married and has had two children. He does not have any access to internet at his house. Moreover, he does not have a smartphone or computer. He would only able to access internet at the office during the recess time. Even though he was not very literate in using internet, he always used any chances to find health information from the internet at the office.

Even though he is a labor worker, he has a health insurance from his institution to cover his family health problem. Thus, there was no difficulty for him to see a doctor due to financial reason. However, as he is aware of any dangerous disease such as stroke and cancer, he used online media to find information to prevent those diseases. According to him, if he or his family suffer from these considered heavy diseases, his insurance will not beneficial for him. Therefore, he will still see a doctor as his primary physician and consider online media as the secondary sources for health information.

These three informants have revealed different level of relationship and reception toward online media as their health educators. The informant 1 was considered as dominant user due to her intensity of using online media to find health information. This informant was looking for credible sources as well in accordance to the willingness of using online media. $\mathrm{Hu}$ and Sundar (2010) stated that people preferred to use website than personal blog or homepage. This influenced how dominant informant differed from negociate informant in selecting the online health sources. In addition, she placed online media as the first source to fulfill her need of health education. She used media both as her primary physician and her educator. The Informant 2, however, had different approach of using online media. Even though she had the easiest access to the internet, she still compromised of using online media as her primary sources of health education. She would prefer to see a doctor if her children were sick. However, she would not see a local doctor but a doctor from another country because she thought those doctors are more 
trusted. Thus, she was considered the negotiated user. The Informant 3 was considered a negotiated user as well in a different level. He had no access to the internet on a daily basis. He would have to go to his office, during a recess time, to access the internet. Because of his internet access and literacy skill, he would still prefer to see doctor as his primary physicians. However, he would always use any chances at his office to access internet to find any information regarding prevention of heavy disease he knows.

The research study concluded that the informants had their own way to select, use, and interact with online media as health sources. This was linear with what Van Dijk and Hacker (2003) and Chang, et al (2012 cited in Chang, Y., Wong, F., \& Park, M., 2014), who proposed four facets as factors of digital divide: technological access, social access, motivational access, and skill access. However, for the informants, the motivational access was used more intensely than technological and skill access to decide whether they would use social media as their doctor or not. To determine the objectivity of the study, the researchers conducted the source and data triangulation simultaneously in the data description. It was due to the nature of the research, which was exploring individual's reception towards social text

\section{CONCLUSION}

This paper depicted how people from a certain background receive online media as health educator. The research study has conducted through several processes of interview and observation with some selected informants. The research study revealed that different people from different background would receive online media as their health educator from different levels. The Informant 1 was a dominant user. Even though she was an Indonesian middle class group, she would use online media as her first health educator and doctor. The Informant 2 was one of Indonesian upper class group whose access to the internet is unlimited. However, she would use online media as her health educator if only she or her husband were sick. As for her children, she would prefer to see an expensive health care to get a good treatment. The Informant 3 was an Indonesian lower group. Even though he had no internet access on a daily basis and still saw a doctor as his primary physician, he was aware of various heavy disease and was trying to find the prevention from the internet at his office. From this research study, the researchers concluded that the three informants receive online media as their health educator. However, because of their educational, motivational, social and technological access, they performed different approach of receiving online media as their health educator. The researchers suggested the existence of further research using a quantitative approach to survey people in Surabaya, who use the Internet in their daily lives, specifically for those who considered mother or housewife as the decision makers in health affairs.

\section{REFERENCES}

Baran, S., Davis, D. K. (2006). Mass communication theory: Foundation, ferment, and future. Belmont, CA: Thomson Wadsworth.

Chang, Y., Wong, F., \& Park, M. (2014). A three-tier ICT access model for intention to participate online: A comparison of developed and developing countries. Information Development, 02666 66914529294, first published on April 10, 2014. Retrieved from: A three-tier ICT access model for intention to participate online: a comparison of developed and developing countries

Hu, Y., Sundar, S. (2010). Effects of online health sources on credibility and behavioral intentions. Communication Research, 2010, 37(1), 105 132. Retrieved from: http://crx.sagepub.com. ezproxy.biola.edu/content/37/1/105.full.pdf $+\mathrm{html}$

Humpreys, S., Rodger, D., Flabouris, M. (2013). Understanding the role of medium in the control and flows of information in health communication. Asia Pacific Media Educator, 2013, 23(2), 291-307. Retrieved from: http://ame.sagepub. com.ezproxy.biola.edu/content/23/2/291.abstract Jensen, and Jankowski. (1991). A Handbook of Qualitative Methodologies for Mass Communication: London: Routledge

Jensen, and Jankowski. (2003). A Handbook of Qualitative Methodologies for Mass Communication: London: Routledge

Kaye, K., Novell, M.K. (1994). Health practices and indices of a poor urban population in Indonesia part I: Patterns of health service utilization. Asia Pac J Public Health, 7(178). DOI: 10.1177/ 101053959400700306. Retrieved from: http:// aph.sagepub.com/content/7/3/178

Korda, H., Itani, Z. (2013). Harnessing social media for health promotion and behavior change. Health Promotion Practice, 2013,. 14(1), 15-23. Retrieved from: http://hpp.sagepub.com.ezproxy.biola.edu/content/14/1/15.full

Schiavo, R. (2008). The rise of E-Health: Current trends and topics on online health communications. Journal of Medical Marketing: Device, 
Diagnostic and Pharmaceutical Marketing, 2008, 8(1), 9-18. Retrieved from: http://mmj. sagepub.com.ezproxy.biola.edu/content/8/1/9.ful l.pdf+html

Schiavo, R. (2007). Health communication: From theory and practice. San Fransisco, CA: JosseyBass.

Soal kesehatan, Indonesia tertinggal dari tetangga. (May, 2013). Retrieved from: http://health. kompas.com/read/2013/05/22/09522188/Soal.K esehatan.Indonesia.Tertinggal.dari.Tetangga
Thomson, R. (2012). Looking healthy: Visualizing mental health and illness online. Visual Coтmunication, November 2012,. 11(4), 395-420. Retrieved from: http://vcj.sagepub.com.ezproxy. biola.edu/content/11/4/395.full

Orang Inggris Pilih Konsultasi ke 'Dokter' Google. (March, 2013). Retrieved from: http://www. tempo.co/read/news/2013/03/22/060468610/Ora ng-Inggris-Pilih-Konsultasi-ke-Dokter-Google 